\title{
Investigation of Different HTF in Indirect Solar Water Heater
}

\author{
M. N. Poshiya ${ }^{1^{*}}$, K. C. Agola ${ }^{2}$ \\ ${ }^{I *}$ Department of Mechanical Engineering, Darshan Institute of Engineering \& Technology Rajkot, Gujarat, INDIA \\ ${ }^{2}$ Department of Mechanical Engineering, Darshan Institute of Engineering \& Technology Rajkot, Gujarat, INDIA
}

\begin{abstract}
Energy usage and energy conservation are greatly inter related and corresponds to a main concern in the world. Renewable energy soUrces are an inevitable in the sustainable development technologies in which the needs of this generation and for next generation for need of energy. Nowadays increasing energy demand and environmental issues have inspired many researchers for searching an alternative option to fulfill the energy demand. In such a case, solar energy appears as the most attractive option due to its abundance and clean feature. Today solar thermal technologies are the popular advanced techniques. The performance of solar thermal technology is dependent on certain factors. Among these factors, heat transfer fluids like water, air, antifreezes like ethylene glycol, propylene glycol, hydrocarbon oils etc. have a very crucial role in heat transfer through the effective utilization of solar thermal energy in solar water heater. The phase changing material (PCM)are latest development in the solar water heater. The system efficiency depends on temperature of the different heat transfer fluids used. Hence their performance analysis. also holds greater importance in this area. In this thesis work, a performance analysis on the solar collector of solar water heater system with different heat transfer fluids is being illustrated. The experiment is conducted using varying concentrations of heat transfer fluid mixture.

The time period of experiment was 22 April to 26 April, 2019. Starting from 08:00 am to 06:00 pm with observation was taken every one and half hour from data logger attached to $\mathrm{J}$ type thermocouples connected to different collectors and different water tanks.
\end{abstract}

Keywords:solar water heater, heat transfer fluid, refrigerant, nanofluid.

\section{Introduction}

The use of solar energy for water heating process is widely used for domestic purpose as well as industrial purpose. There are many factors that affect the performance of solar water heater. In those factors one of the important factors is heat transfer fluid (HTF) of the indirect solar water heating system.

1.1 Types of heat transfer fluid: Heat transfer fluid or solar thermal fluid arecategorized as follow;

1. Water based

2. Oil based

3. Air

4. Molten salts

5. Silicones

6. Refrigerant

All these HTF have their advantages and disadvantages for application of solar water heating.

${ }^{*}$ Corresponding Author: e-mail: mposhiyaa@gmail.com, Tel-+91-7984255936, +91-9879705969

ISSN 2320-7590

(C)2019 Darshan Institute of Engg.\& Tech., All rights reserved
1.2 Key Properties of HTF:Here explained properties of HTF are very important for selecting the HTF for the water heating system. Different HTF have different properties for heating processes, in which some are very crucial for the requirement of the heating process.

1. Specific heat

2. Boiling point

3. Freezing point

4. Density

5. Viscosity

After studying all required properties best HTF should be selected. For use in water heating system the desired properties are; High specific heat, low viscosity, high boiling point, low freezing point etc.

1.3 Purpose of thesis:In this thesis work I have investigated three HTF in indirect solar water heater with flat plate collector. The design of model is referenced from the research paper proposed by M. Esen and H. Esen. ${ }^{[3]}$ There are some modification done for the use of different HTF then them.

The observation of temperature hourly during the day done and then calculate the efficiency of overall system with 


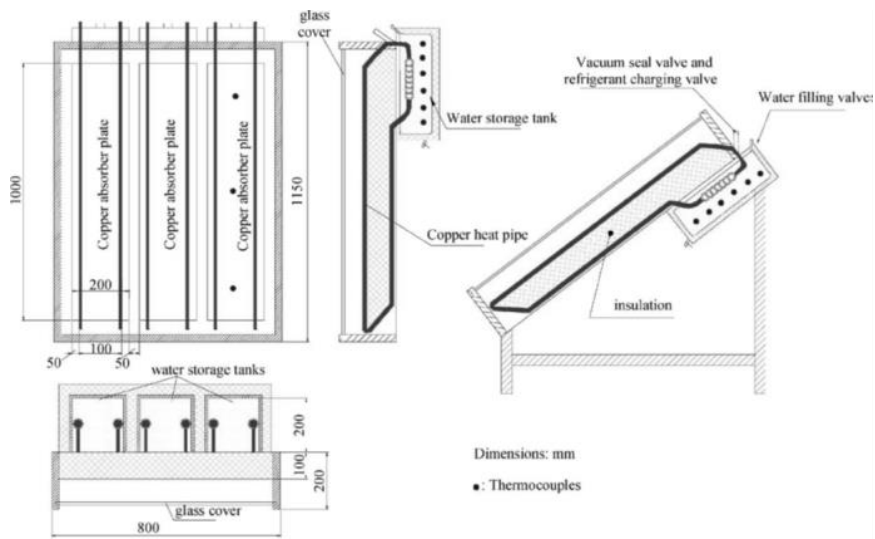

Figure 1. Design Proposed by M. Esen and H. Esen ${ }^{[3]}$

known amount of water heated and initial temperature of water with required properties of HTF.

\section{Experimental setup and Methodology}

A setup is fabricated for the experiment with some changes in design of the referred research paper because in that paper they investigated only refrigerant. Here I am using three different $\mathrm{HTF}$ as Water-EG mixture, $\mathrm{Al}_{2} \mathrm{O}_{3}$ Nanofluid and Refrigerant R410A. The solar collector used in setup is class 2 flat plate collector with one glass cover.

The experiment of three different HTF was carried out in the same collector but separate and under the same condition side by side. For data collection three system names used as in System 1 for Water-EG system, System 2 for $\mathrm{Al}_{2} \mathrm{O}_{3}$ Nanofluid system and System 3 for refrigerant R410A system.

2.1 Experimental Setup:The dimensions of the components of the setup are as follow.

1. Aluminum Collector case Length: $1150 \mathrm{~mm}$

Width: $800 \mathrm{~mm}$

Height: $150 \mathrm{~mm}$

2. Rockwool Insulation

Thickness: $50 \mathrm{~mm}$

3. Copper absorber plate $(* 3)$

Length: $1000 \mathrm{~mm}$

Width: $200 \mathrm{~mm}$

Thickness: $0.8 \mathrm{~mm}$

4. Copper Heat pipe $(* 6)$

OD: $9.525 \mathrm{~mm}$ (3/8 inch)

Length: $1050 \mathrm{~mm}$

U-shaped for each system consist of two pipes for each system.

5. Copper Pipe Coil $(* 3)$

OD: $9.525 \mathrm{~mm}$ (3/8 inch)
Length: $900 \mathrm{~mm}$

Four rounds in each coil.

6. Glass Cover

Thickness: $4 \mathrm{~mm}$

Air Gap: $30 \mathrm{~mm}$

The fabricated setup photos are presented here in figure 2 below.There are two thermocouples attached with each absorber plate and one thermocouple is attached in each water tank. Thus total nine thermocouples are attached in system.

2.2 Information of HTF:The three different HTF used are Water-Ethylene Glycol mixture, Al2O3 blend in Ethylene Glycol with water based nanofluid and R410A refrigerant.

- Water and Ethylene glycol is mixed 50-50 by $\%$ volume and total of $125 \mathrm{ml}$ is filled in first system of collector.

- $\mathrm{Al} 2 \mathrm{O} 3$ nanoparticles of size $\sim 50 \mathrm{~nm}$ is blended in 25 $\mathrm{ml}$ Ethylene glycol and then mixed well with stirrer in $100 \mathrm{ml}$ water to prepare total $125 \mathrm{ml}$ of nanofluid and filled in second system of collector.

- The standard refrigerant R410A of $100 \mathrm{gm}$ is filled in third system of collector checked for the leakage.

The Experiment is carried out at Surat (Latitude-21.1702 N, 72.8311 E) during $22^{\text {nd }}$ April to $26^{\text {th }}$ April from 08:00 am to $06: 00 \mathrm{pm}$.
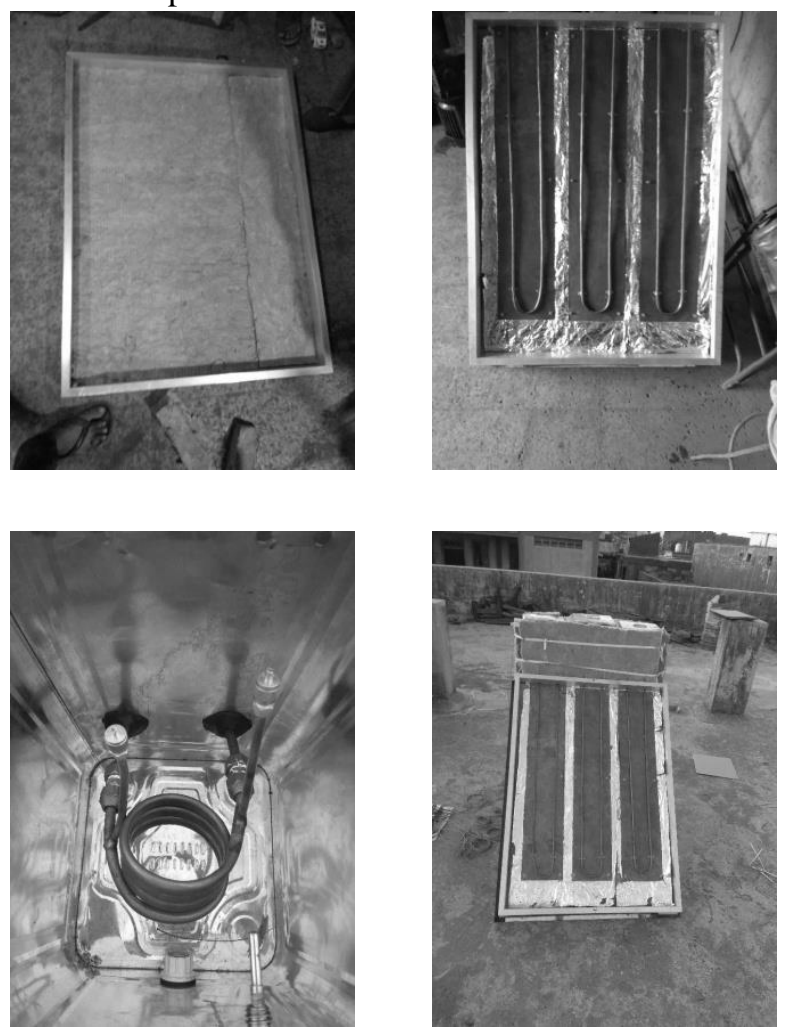

Figure 2.Actual Setup 
2.3 Experiment Method:The experiment was carried out as given above for 5 days from $22^{\text {nd }}$ April to $26^{\text {th }}$ April. To measure the temperature $\mathrm{J}$ type thermocouples are used. The global radiation for the location is taken average $400 \mathrm{~W} / \mathrm{m}^{2}$. The temperature is read on the digital reader with relay system to note all different temperature at same time by pressing switch of each thermocouple.

Steps of experiment:

1. Uncover the system and fill all tanks with 15 liter of water, take the measurement of temperature of all three collectors and three water tanks and also ambient temperature.

2. After that in every one and half hour take the measurements of collectors and waters in tank.

3. This process is done at 09:30 am, 11:00 am, 12:30 pm, 03:00 pm, 04:30 pm and 06:00 pm.

4. Measurement of all nine temperatures is done for each system at a time.

5. For calculation of efficiency the area of each collector and average global radiation at location is used with measured temperatures.

6. This procedure is carried out for 5 days in a row and information collected from experiment is discussed in result.

\section{Result and Discussion}

The temperature measurement for system 1 with Water-EG, system 2 with nanofluid and system 3 with refrigerant is used as HTF. The different measurement at different time for collector of system 1,2 and 3 is as follows.

Table 1.System 1 collector temperatures

\begin{tabular}{|c|c|c|c|c|c|c|c|c|c|c|}
\hline Date & $22 / 04$ & $23 / 04$ & $24 / 04$ & $25 / 04$ & \multicolumn{2}{|c|}{$26 / 04$} \\
\hline Sensor & 1 & 2 & 1 & 2 & 1 & 2 & 1 & 2 & 1 & 2 \\
\hline Time & \multicolumn{10}{|c|}{ Temperature ${ }^{\circ} \mathrm{C}$} \\
\hline $08: 00$ & 30 & 29 & 31 & 30 & 31 & 31 & 33 & 32 & 30 & 29 \\
\hline $09: 30$ & 60 & 59 & 63 & 61 & 62 & 62 & 64 & 62 & 61 & 60 \\
\hline $11: 00$ & 76 & 75 & 77 & 76 & 75 & 75 & 78 & 76 & 76 & 73 \\
\hline $12: 30$ & 89 & 88 & 91 & 90 & 90 & 90 & 88 & 87 & 90 & 88 \\
\hline $03: 00$ & 88 & 87 & 88 & 88 & 87 & 86 & 86 & 85 & 88 & 86 \\
\hline $04: 30$ & 65 & 63 & 66 & 65 & 65 & 62 & 64 & 63 & 66 & 65 \\
\hline $06: 00$ & 43 & 42 & 45 & 44 & 44 & 44 & 46 & 45 & 45 & 42 \\
\hline
\end{tabular}

Table 2.System 1 collector maximum temperature

\begin{tabular}{|c|c|c|c|c|c|}
\hline Date & $22 / 04$ & $23 / 04$ & $24 / 04$ & $25 / 04$ & $26 / 04$ \\
\hline Temp. & 89 & 91 & 90 & 88 & 90 \\
\hline
\end{tabular}

The daily maximum temperature is plotted with daily temperature in graph below. This detail is used for calculation of collector heat gain and overall efficiency of the system.

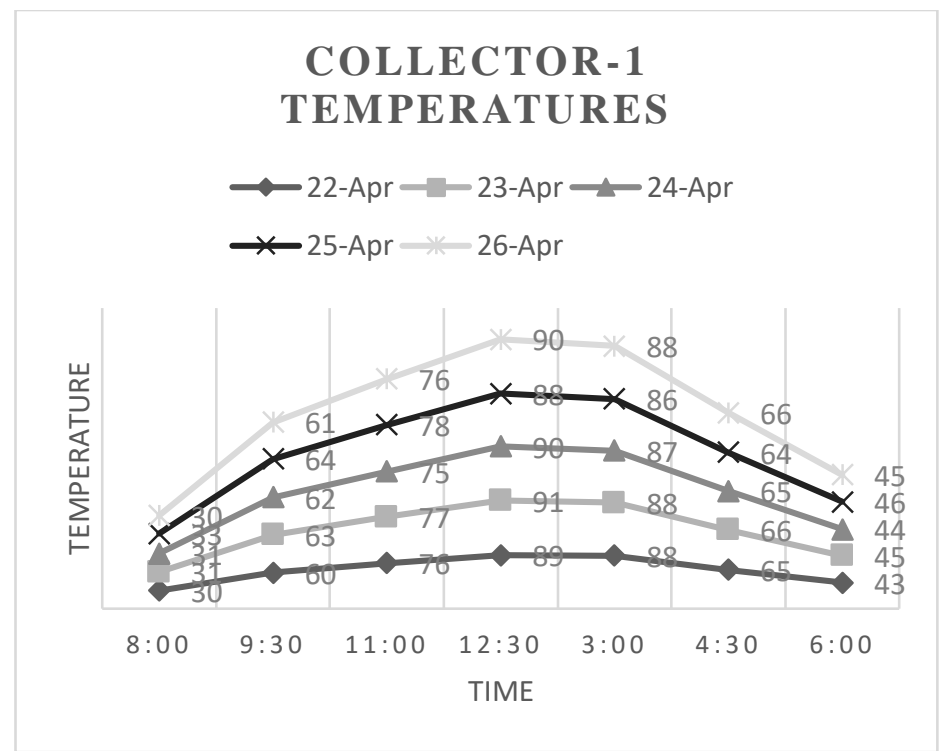

Figure 3.Daily temperature of collector 1

Table 3.System 2 collector temperatures

\begin{tabular}{|c|c|c|c|c|c|c|c|c|c|c|}
\hline Date & $22 / 04$ & $23 / 04$ & $24 / 04$ & $25 / 04$ & $26 / 04$ \\
\hline Sensor & 1 & 2 & 1 & 2 & 1 & 2 & 1 & 2 & 1 & 2 \\
\hline Time & \multicolumn{8}{|c|}{ Temperature ${ }^{\circ} \mathrm{C}$} \\
\hline $08: 00$ & 28 & 28 & 30 & 29 & 29 & 29 & 28 & 27 & 29 & 28 \\
\hline $09: 30$ & 61 & 60 & 63 & 62 & 61 & 60 & 60 & 60 & 63 & 62 \\
\hline $11: 00$ & 75 & 74 & 78 & 77 & 77 & 76 & 76 & 76 & 75 & 74 \\
\hline $12: 30$ & 87 & 87 & 90 & 90 & 88 & 88 & 89 & 88 & 88 & 88 \\
\hline $03: 00$ & 81 & 80 & 82 & 82 & 80 & 79 & 81 & 80 & 82 & 81 \\
\hline $04: 30$ & 63 & 62 & 65 & 64 & 64 & 64 & 63 & 62 & 63 & 62 \\
\hline $06: 00$ & 44 & 42 & 45 & 44 & 44 & 43 & 43 & 42 & 44 & 44 \\
\hline
\end{tabular}

Table 4.System 2 collector maximum temperature

\begin{tabular}{|c|c|c|c|c|c|}
\hline Date & $22 / 04$ & $23 / 04$ & $24 / 04$ & $25 / 04$ & $26 / 04$ \\
\hline Temp. & 87 & 90 & 88 & 89 & 88 \\
\hline
\end{tabular}

\section{COLLECTOR - 2} TEMPERATURES

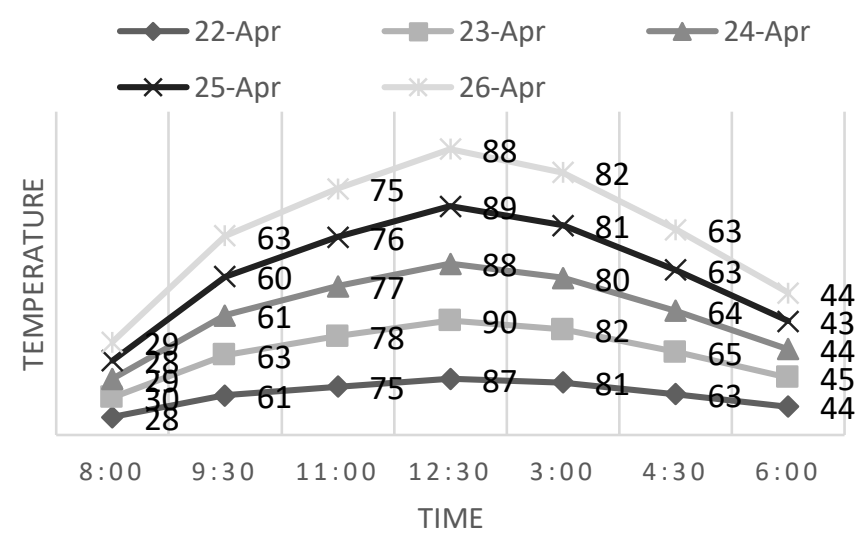

Figure 4.Daily temperature of collector 2 
Table 5.System 3 collector temperatures

\begin{tabular}{|c|c|c|c|c|c|c|c|c|c|c|}
\hline Date & $22 / 04$ & $23 / 04$ & $24 / 04$ & $25 / 04$ & \multicolumn{2}{|c|}{$26 / 04$} \\
\hline Sensor & 1 & 2 & 1 & 2 & 1 & 2 & 1 & 2 & 1 & 2 \\
\hline Time & \multicolumn{10}{|c|}{ Temperature ${ }^{\circ} \mathrm{C}$} \\
\hline $08: 00$ & 30 & 29 & 30 & 29 & 29 & 28 & 28 & 28 & 29 & 29 \\
\hline $09: 30$ & 60 & 59 & 62 & 61 & 60 & 59 & 60 & 59 & 61 & 60 \\
\hline $11: 00$ & 77 & 75 & 79 & 78 & 78 & 76 & 77 & 76 & 78 & 77 \\
\hline $12: 30$ & 82 & 81 & 84 & 83 & 84 & 84 & 83 & 82 & 85 & 84 \\
\hline $03: 00$ & 71 & 71 & 72 & 71 & 71 & 70 & 73 & 72 & 73 & 73 \\
\hline $04: 30$ & 62 & 62 & 61 & 61 & 62 & 61 & 63 & 62 & 64 & 62 \\
\hline $06: 00$ & 42 & 41 & 43 & 43 & 42 & 42 & 44 & 43 & 44 & 43 \\
\hline
\end{tabular}

Table 6.System 3 maximum temperature

\begin{tabular}{|c|c|c|c|c|c|}
\hline Date & $22 / 04$ & $23 / 04$ & $24 / 04$ & $25 / 04$ & $26 / 04$ \\
\hline Temp. & 82 & 84 & 84 & 83 & 85 \\
\hline
\end{tabular}

\section{COLLECTOR-3 TEMPERATURE}
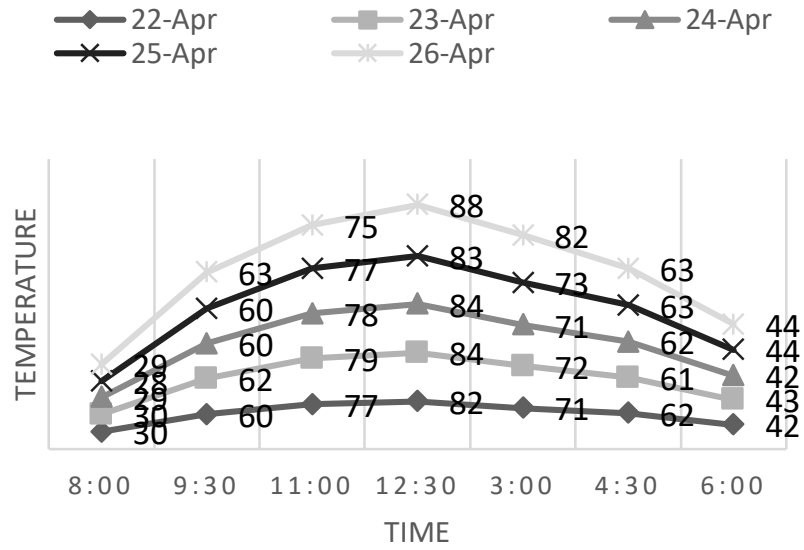

Figure 5. Daily temperature of collector 3

The temperature of water tanks are measured for each system and noted in table below.

Table 7. Water tank temperature system 1

\begin{tabular}{|c|c|c|c|c|c|}
\hline Date & $22 / 04$ & $23 / 04$ & $24 / 04$ & $25 / 04$ & $26 / 04$ \\
\hline Time & \multicolumn{5}{|c|}{ Temperature $^{\circ} \mathrm{C}$} \\
\hline $08: 00$ & 25 & 26 & 25 & 27 & 26 \\
\hline $09: 30$ & 39 & 40 & 40 & 41 & 39 \\
\hline $11: 00$ & 48 & 50 & 49 & 52 & 49 \\
\hline $12: 30$ & 51 & 53 & 52 & 54 & 51 \\
\hline $03: 00$ & 58 & 60 & 59 & 59 & 57 \\
\hline $04: 30$ & 55 & 57 & 57 & 56 & 55 \\
\hline $06: 00$ & 49 & 48 & 48 & 49 & 47 \\
\hline
\end{tabular}

Table 8. Water tank temperature system 2

\begin{tabular}{|c|c|c|c|c|c|}
\hline Date & $22 / 04$ & $23 / 04$ & $24 / 04$ & $25 / 04$ & $26 / 04$ \\
\hline Time & \multicolumn{5}{|c|}{ Temperature ${ }^{\circ} \mathrm{C}$} \\
\hline $08: 00$ & 25 & 26 & 25 & 27 & 26 \\
\hline $09: 30$ & 38 & 40 & 38 & 39 & 41 \\
\hline $11: 00$ & 46 & 48 & 47 & 49 & 50 \\
\hline $12: 30$ & 53 & 51 & 50 & 52 & 53 \\
\hline $03: 00$ & 56 & 55 & 54 & 55 & 56 \\
\hline $04: 30$ & 52 & 53 & 51 & 51 & 52 \\
\hline $06: 00$ & 45 & 44 & 42 & 43 & 45 \\
\hline
\end{tabular}

Table 9. Water tank temperature system 3

\begin{tabular}{|c|c|c|c|c|c|}
\hline Date & $22 / 04$ & $23 / 04$ & $24 / 04$ & $25 / 04$ & $26 / 04$ \\
\hline Time & \multicolumn{5}{|c|}{ Temperature ${ }^{\circ} \mathrm{C}$} \\
\hline 08:00 & 25 & 26 & 25 & 27 & 26 \\
\hline $09: 30$ & 37 & 39 & 38 & 40 & 41 \\
\hline $11: 00$ & 48 & 49 & 47 & 51 & 52 \\
\hline $12: 30$ & 52 & 55 & 51 & 54 & 55 \\
\hline 03:00 & 60 & 61 & 59 & 59 & 61 \\
\hline $04: 30$ & 58 & 59 & 55 & 55 & 57 \\
\hline 06:00 & 50 & 52 & 51 & 53 & 52 \\
\hline
\end{tabular}

Table 10. Daily maximum water temperature

\begin{tabular}{|c|c|c|c|c|c|}
\hline Date & $22 / 04$ & $23 / 04$ & $24 / 04$ & $25 / 04$ & $26 / 04$ \\
\hline System & \multicolumn{5}{|c|}{ Temperature ${ }^{\circ} \mathrm{C}$} \\
\hline Tank 1 & 58 & 60 & 59 & 59 & 57 \\
\hline Tank 2 & 56 & 55 & 54 & 55 & 56 \\
\hline Tank 3 & 60 & 61 & 59 & 59 & 61 \\
\hline
\end{tabular}

\section{Daily max. water temperature}

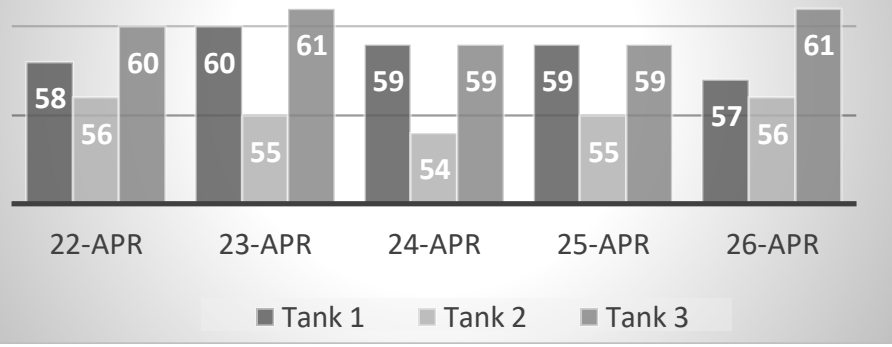

Figure 6. Daily maximum water temperature 
To calculate overall system efficiency consider the equation used for the closed cycle solar water heater with fixed amount of water to be heated.

$$
\eta=\frac{\mathrm{mw} \operatorname{Cp}, \mathrm{w}(\mathrm{Tw} 2-\mathrm{Tw} 1)}{A \operatorname{Ig}}
$$

Where, $\mathrm{mw}$ is mass of water in tank, $\mathrm{Cp}, \mathrm{w}$ is specific heat related to water, (Tw2-Tw1) is temperature rise, $\mathrm{A}$ is collector area and Ig is average global radiation.

Mass of water of 15 liter water $\mathrm{mw}=15 \mathrm{~kg}$ and specific heat of water $\mathrm{Cp}, \mathrm{w}=4.2 \mathrm{~kJ} / \mathrm{kg}{ }^{\circ} \mathrm{C}$, Area of each collector $\mathrm{A}=0.2$ $\mathrm{m}^{2}$ and Average Global radiation $\mathrm{Ig}=299 \mathrm{~W} / \mathrm{m}^{2}$.

From Table 10average maximum temperature of water in tank 1 is Tw $2=58.6{ }^{\circ} \mathrm{C}$ and from Table 7 average of initial temperature of water in tank 1 is $\mathrm{Tw} 1=25.8^{\circ} \mathrm{C}$.

Overall efficiency of system 1 with Water-EG as HTF is,

$$
\eta_{1}=34.55 \%
$$

From Table 10average maximum temperature of water in tank 2 is Tw $2=55.2{ }^{\circ} \mathrm{C}$ and from Table 8 average of initial temperature of water in tank 2 is $\mathrm{Tw} 1=25.8^{\circ} \mathrm{C}$.

Overall efficiency of system 2 with nanofluid as HTF is,

$$
\eta_{2}=30.97 \%
$$

From Table 10average maximum temperature of water in tank 3 is Tw $2=60{ }^{\circ} \mathrm{C}$ and from Table 9 average of initial temperature of water in tank 3 is Tw $1=25.8^{\circ} \mathrm{C}$.

$$
\eta_{3}=36.03 \%
$$

\section{Conclusions}

- Experiments have been carried out on a solar water heater containing three different collector system under one condition to investigate the performance of different heat transfer fluid for water heating and this all three systems of different heat transfer fluid were cascaded in on collector box.

- The system containing refrigerant R410A as HTF gave the highest hot water temperature, $61{ }^{\circ} \mathrm{C}$. For other two systems containing water-EG mixture gave maximum hot temperature of $60{ }^{\circ} \mathrm{C}$ and Nanofluid system gave the minimum hot water temperature of $56^{\circ} \mathrm{C}$.

- As in concern of collector temperature, the highest collector temperature was $91{ }^{\circ} \mathrm{C}$ for water-EG system.
- For daily observation of temperature from the morning to evening, we can say that the maximum output of system was at the time period of $12 \mathrm{pm}$ to $3 \mathrm{pm}$. After that the temperature is starting to getting down from the maximum of it.

- The overall efficiency of three systems are from high to low as system 3 has $36.03 \%$, system 1 has $34.55 \%$ and system 2 has $30.97 \%$.

- So we can see that the system with refrigerant has the highest efficiency of all and can be further more improved by using full working model of refrigerant closed cycle solar water heater with more heat pipes as per water requirement.

\section{Nomenclature}

HTF - Heat Transfer Fluid

EG - Ethylene Glycol

$\mathrm{Mw}$ - Mass of Water

$\mathrm{Cp}, \mathrm{w}$ - Specific heat of Water

Tw1 - Initial Water Temperature

Tw2 - Hot Water Temperature at Time

A - Area of Collector

Ig - Average Global Radiation

$\eta$ - Overall Efficiency

\section{Acknowledgement}

I would like to thank my dissertation guide Prof. Ketan C. Agola for providing a vision about the dissertation. I have been greatly benefited from the regular critical reviews and inspiration throughout my work.

\section{References}

1. Yimin Xuan and Qiang $\mathrm{Li}$, Heat transfer enhancement of nano fluids, International Journal of Heat and Fluid Flow, Vol. 21, No. 1, pp. 58-64, 2000.

2. Belen Zalba, Jose Ma Marin, Luisa F. Cabeza and Harald Mehling, Review on thermal energy storage with phase change: materials, heat transfer analysis and applications, Vol. 23, No. 3, pp. 251-380, 2003.

3. Mehmet Esen and Hikmet Esen, Experimental investigation of a two-phase closed thermosyphon solar water heater, Solar Energy, Vol. 79, No. 5, pp459-468, 2005

4. Vikram D, kaushik S, Prashanth V and Nallusamy $\mathrm{N}$, An improvement in the solar water heating system by thermal storage using phase change materials, Proc. ASME 2006 International Solar Energy Conference, pp. 409-416, 2006.

5. Ahmet Sari, Ali Karaipekli, Thermal conductivity and latent heat thermal energy storage characteristics of paraffin/expanded graphite composite as phase 
change material, Applied Thermal Engineering, Vol. 27, No. 8-9, pp. 1271-1277, 2007

6. I. Budihardjo , G.L. Morrison, Performance of water-in-glass evacuated tube solar water heaters, Solar Energy, Vol. 83, No. 1, pp. 49-56, 2009

7. Jinbao Huang, Shaoxuan Pu, Wenfeng Gao, YiQue, Experimental investigation on thermal performance of thermosyphon flat-plate solar water heater with a mantle heat exchanger, Energy, Vol. 35, No. 9, pp. 3563-3568, 2010

8. Ruobing Liang ,Liangdong Ma ,Jili Zhang, Dan Zhao,Theoretical and experimental investigation of the filled-type evacuated tube solar collector with $\mathrm{U}$ tube, Solar Energy, Vol. 85, No. 9, pp. 1735-1744, 2011

9. Ruchi Shukla, K.Sumathy, Phillip Erickson, Jiawei Gong, Recent advances in the solar water heating systems: A review, Renewable and Sustainable Energy Reviews, Vol. 19, pp. 173-190, 2013

10. Ayompe, L. and Duffy, A. Analysis of the thermal performance of a solar water heating system with flat plate collectors in a temperate climate. Applied Thermal Engineering : 58; pp. 447-454, 2013
11. Sharif, M. K. A., Al-Abidi, A. A., Mat, S., Sopian, K., Ruslan, M. H., Sulaiman, M. Y., \& Rosli, M. A. M. Review of the application of phase change material for heating and domestic hot water systems. Renewable and Sustainable Energy Reviews, Vol. 42, pp. 557-568, 2015

12. Srivastva U, Malhotra RK, Kaushik SC (2015) Recent Developments in Heat Transfer Fluids Used for Solar Thermal Energy Applications. Journal of Fundamentals of Renewable Energy and Applications, Vol, 5, pp.189

13. Jeena John, Nidhi M J, A Review on Performance of Solar Thermal Flat plate collector using different Heat transfer Fluid, International Journal Of Current Engineering And Scientific Research, , Vol 2, No.7,pp. 204-210, 2015

14. Himsar Ambarita, Tekad Sitepu, Experimental study on a prototype solar water heater using refrigerant $\mathrm{R} 141 \mathrm{~b}$ as a transfer fluid, Materials Science and Engineering Vol. 237, pp. 012-014, 2017

15. S. P. Sukhatme, Solar Energy: Principles of Thermal Collection and Storage, 2009

\section{Biographical notes}

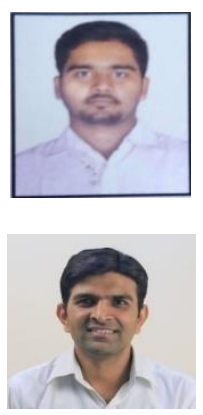

Mehul N. PoshiyaPursuing M.E. in Thermal Engineering from Darshan Institute of Engineering \& Technology, Rajkot, Gujarat, India.

Ketan C. Agola has received M. Tech. in Thermal Engineering from Sri SatyaSai Institute of Science \& Technology in 2012. He is assistant professor in Mechanical Department of Darshan Institute of Engineering \& Technology, Rajkot, Gujarat, India. 